\title{
KAJIAN TEORI ANDROGINI TERHADAP JENIS PERMAINAN DALAM PEMAHAMAN KARAKTER GENDER ANAK
}

\section{Zaifullah}

\begin{abstract}
His paper is a literature review to explain the Androgyny theory of types of games in shaping the understanding of children's gender roles. The androgyny theory is expected to be able to change people's views about people's understanding of gender and gender which is very influential in the selection of games for young children so that it is considered very important to understand the difference between sex and gender.
\end{abstract}

Keywords : Game, Androgyny, Gender

\section{PENDAHULUAN}

Bermain merupakan fitrah yang tak dapat dipisahkan dari kehidupan anakanak dengan bermain anak-anak dapat berkembang sebagaimana mestinya dengan bermain anak-anak dapat memberikan kesenangan, membentuk kepribadian, perkembangan fisik, perkembangan intelektual, sosial, moral dan emosional. berbagai jenis permainan tersedia baik permainan tradisional maupun permainan modern, permainan yang melibatkan fisik maupun permainan yang tidak melibatkan fisik.

Perkembangan teknologi saat ini sangat mempengaruhi jenis-jenis permainan yang tersedia, kesiapan terhadap permainan tersebut menjadi sebuah tantangan di era saat ini, karena hal tersebut dibutuhkan peran orang tua terhadap pemilihan jenis-jenis permainan yang dibutuhkan oleh anak.

Pada dasarnya permainan anak yang banyak dijumpai saat ini menawarkan banyak pilihan, namun ada yang terlupakan dengan banyaknya jenis permainan yang tersedia saat ini yaitu kebutuhan anak akan jenis permainan yang pada akhirnya berdampak pada perkembangan psikologi anak.

Jenis kelamin merupakan pembagian dua jenis kelamin manusia yang ditentukan secara biologis yang melekat pada jenis kelamin tertentu dan tidak bisa 
diubah. ${ }^{1}$ Pemahaman masyarakat terhadap perbedaan jenis kelamin sering di persepsikan sama gender dan jenis kelamin memiliki definisi yang sama, namun ketika kita cermati pada dasarnya gender dan jenis kelamin memiliki perbedaan, jenis kelamin merujuk pada penciri biologis yang tidak diubah sedangkan gender meupakan "suatu sifat yang melekat pada kaum laki-laki maupun perempuan yang dikonstruksi secara sosial maupun kultural" 2

Selanjutnya dalam memberikan pemahaman pembentuk gender pada anak dipengaruhi oleh banyak hal salah satu diantaranya ada lingkungan keluarga yang merupakan hal yang paling dekat dan yang pertama dijumpai oleh anak sebelum berinteraksi dengan dunia luar, sehingga dianggap penting memberikan pemahaman terhadap peran gender sebuah hal yang penting dikarenakan pada anak usia dini merupakan usia yang paling tepat untuk memberikan pemahaman terhadap peran gender sebagaimana adanya anggapan lebih gampang membengkokkan bambu yang masih hijau dari pada membengkokkan bambu yang sudah tua.

Istilah androgini yang berkembang dalam masyarakat merujuk pada prilaku yang menyimpang dari kodratnya seperti laki-laki yang berprilaku seperti perempuan atau sebaliknya. Pernyataan tersebut tidak dapat dipungkiri ketika melihat hal tersebut dari sudut pandang sosiokultural, androgini dianggap sebagai kelainan orientasi dalam gaya hidup semisal dengan penyebutan gemulai bahkan "banci" kelainan orientasi yang dimaksud adalah pria yang berprilaku seperti wanita atau sebaliknya wanita berprilaku sebagai pria.

Tentunya ketika membahas tentang permainan anak pada kebutuhan jenis permainan anak harus melihat pada kebutuhan bagaimana jenis permainan tersebut dapat membentuk karakter anak, khususnya pada tulisan ini akan melihat pada jenis pemilihan permainan anak yang akan berdampak pada pemahaman dan pembentukan gender anak.

1 Riant Nugroho, 2008, Gender dan Administrasi Publik, Yogyakarta: Pustaka Pelajar, h.30.

2 Fakih, Mansour. 2008 Analisis Gender \& Transformasi Sosial. Yogyakarta: Pustaka Belajar, 2004. hlm, 7 
Dengan semakin banyaknya jenis permainan yang tersedia dan bagaimana pentingnya peran orang tua dalam memahami jenis kelamin dan gender dan pemilihan permainan guna membentuk gender anak maka penulis akan mengkaji Teori Androgini terhadap Jenis Permainan dalam Pembentukan Pemahaman Karakter Gender Anak.

\section{PEMBAHASAN}

\section{Permainan}

Bermain merupakan bagian dari kehidupan anak-anak, bermain bagi anak merupakan sesuatu yang tidak dapat dipisahkan bahkan terkadang dalam hal apapun yang dilakukan oleh anak-anak selau dibarengi dengan bermain Dalam hal ini, aktivitas bermain yang dilakukan anak-anak merupakan cerminan kemampuan fisik, intelektual, emosional dan sosial.

Bermain pada anak usia tertentu merupakan kegiatan yang dilakukan semata-mata demi mendapatkan kesenangan semata, dan tidak melihat permainan tersebut sebagai kompetisi. Dalam perkembangannya ada yang berpendapat bahwa anak yang terlalu banyak bermain dianggap nakal akan membuat menjadi malas sehingga menghambat peningkatan intelektual anak, namun jika dilihat dari satu sisi pendapat tersebut kurang begitu tepat dan bijaksana, sebab beberapa ahli psikologi dan ahli perkembangan psikologi anak sepakat permainan dianggap memberi pengaruh yang masiv terhadap perkembangan anak.

Pada dasarnya permainan anak melibatkan kegiatan fisik maupun permainan yang tidak melibatkan fisik, seiring perkembangan anak akan melalui tahapan-tahapan, hal ini tak lepas dari perkembangan otak dan psikologi anak

Tahap-tahap perkembangan bermain Menurut Jean Piaget tahapan perkembangan bermain anak dapat diklasifikasikan menjadi beberapa kelompok sebagai berikut:

1. Sensori motor (sensory motor play) Tahap ini terjadi pada anak usia 0-2 tahun. Pada tahap ini bermain anak lebih mengandalkan indra dan gerakgerak tubuhnya. Untuk itu, pada usia ini mainan yang tepat untuk anak ialah yang dapat merangasang panca indranya, misalanya mainan yang berwarna cerah, memiliki banyak bentuk dan tekstur, serta mainan yang tidak mudah tertelan oleh anak. 
205 | MUSAWA, Vol. 11 No. 2 Desember 2019 : 202 - 221

2. Praoprasional (symbolic play) Tahap ini terjadi pada anak usia 2-7 tahun. Pada tahap ini anak sudah mulai bisa bermain khayal dan pura-pura, banyak bertanya, dan mulai mencoba hal-hal baru, dan menemui simbolsimbol tertentu. Kecendrungan permainan yang cocok diusia tersbut adalah yang mampu merangsang perkembangan imajinasi anak, seperti menggambar, balok/lego, dan puzzle. Namun sifat permainan anak usia dini lebih sederhana dibandingkan dengan operasional konkret.

3. Operasional konkret (social play) ahap ini terjadi pada anak usia 7-11 tahun. Pada tahap ini anak bermain sudah menggunakan nalar dan logika yang bersifat objektif. Di tahap ini permaian yang digunakan adalah permainan mampu menstimulasi cara berpikir anak. Melalui alat permainan yang dimainkan anak dapat menggunakan nalar maupun logikanya dengan baik. Contoh permainan yang bisa digunakan di antaranya: dakon, puzzle, ular tangga, dam-daman, dan monopoli.

4. Formal operasional (game with rules and sport) Terjadi pada tahap anak usia 11 tahun ke atas. Pada tahap ini anak bermain sudah menggunakan aturan-aturan yang sangat ketat dan lebih mengarah pada game atau pertandingan yang menuntuk adanya menang dan kalah. Pada tahap ini biasaya permainan yang dimainkan telah menjurus pada permainan resmi yang dipertandingkan pada tingkat lokal, nasional dan internasional. ${ }^{3}$

Tahapan permainan pada anak usia dini menurut Mildred Parten. dalam

Tedjasaputra mengklasifikasikan tahapan-tahapan bermain anak, yakni:

1. Unoccupied Play (permainan kentara), dimana anak tidak benar- benar terlibat dalam kegiatan main, melainkan hanya mengamati kejadian disekitarnya yang menarik perhatian anak.

2. Solitary Play (bermain sendiri), anak sibuk bermain sendiri dan tidak memperhatikan kehadiran anak-anak lain disekitarnya.

3. Onlooker Play (pengamatan), kegiatan bermain dengan mengamati anakanak lain yang sedang melakukan kegiatan main sehingga timbul minat terhadap permainan tersebut.

4. Parallel Play (bermain pararel),bermain dengan melakukan kegiatan yang sama secara sendiri-sendiri pada saat yang bersamaan, misalnya bermain mobil-mobilan.

5. Associative Play (bermain asosiatif), adanya interaksi antar anak yang bermain, saling tukar alat permainan, tetapi bila diamati akan tampak masing-masing anak sebenarnya tidak terlibat dalam kerjasama, misalnya anak yang sedang menggambar, saling berbagi pensil warna,dsb.

6. Cooperative Play (bermain bersama), adanya kerjasama atau pembagian tugas dan pembagian peran antar anak-anak yang terlibat dalam permainan untuk mencapai satu tujuan tertentu. ${ }^{4}$

3 M. Fadlillah, M.Pd.I. 2017 Bermain \& Permainan Anak Usia Dini, Jakarta: Kencana, hal. 43

4 Tedjasaputra, Mayke S. (2001). Bermain, Mainan, dan Permainan. Jakarta: PT. Grasindo. hal. 21 
Tahap permainan tersebut dapat terlihat adanya tahapan peningkatan jika dilihat dari segi intensitas interaksi sosial mulai dari kegiatan bermainan yang hanya melibatkan si anak sendiri dengan menggunakan imajinasinya sampai dengan Kegiatan yang melibatkan orang lain.

\section{Jenis Kelamin dan Gender}

Menurut Hungu jenis kelamin (seks) adalah perbedaan antara perempuan dengan laki-laki secara biologis sejak seseorang lahir. Jenis kelamin berkaitan dengan perbedaan fungsi bentuk tubuh laki-laki dan perempuan, dimana laki-laki memproduksikan sperma dan perempuan menghasilkan sel telur dan secara biologis mampu untuk menstruasi, hamil dan menyusui. Perbedaan biologis dan fungsi biologis laki-laki dan perempuan tidak dapat ditukar diantara keduanya, dan fungsinya tetap dengan laki-laki dan perempuan. ${ }^{5}$

Moore dan Sinclair Jenis kelamin mengacu pada perbedaan biologis antara tubuh laki-laki dan perempuan, yang merupakan hasil dari perbedaan kromosom dan embrio. ${ }^{6}$

Dalam islam dijelaskan dalam al-Qur'an Dan bahwasanya Dialah yang menciptakan berpasang-pasangan pria dan wanita. Dari air mani, apabila dipancarkan," bunyi Surah An-Najm: 45-46. ${ }^{7}$

Selanjutnya dalam surah Al-Qiyamah Ayat 37-39. Bukankah dia dahulu setetes mani yang ditumpahkan (ke dalam rahim), kemudian mani itu menjadi segumpal darah, lalu Allah menciptakannya, dan menyempurnakannya, lalu Allah menjadikan daripadanya sepasang: laki-laki dan perempuan," 8

Secara explisit ayat tersebut menjelaskan bahwa jenis kelamin dibedakan menjadi dua yaitu laki-laki dan perempauan secara kodrat manusia dilihat dari

\footnotetext{
5 Hungu. 2007.Pengertian Jenis Kelamin. Dapat dibuka pada situs http://www.scribd.com/doc/143354392/BABII-Tinjauan-Gender diakses paka pukul 1 Januari 2019 6 Sinclair 1995 pengertian jenis kelamin, dapat dibuka pada situs http://www.scribd.com/doc/143354392/BABII-Tinjauan-Gender

7 Al-Quran Terjemahan. 2015. Departemen Agama RI. Bandung: CV Darus Sunnah. 8 Al-Quran Terjemahan. 2015. Departemen Agama RI. Bandung: CV Darus Sunnah.
} 
jenis kelamin secara biologis yaitu laki-laki dan perempuan, sehingga tidak dikenal dengan adanya jenis kelamin "ketiga"

Kata "Gender" berasal dari bahasa Inggris, gender, berarti "jenis kelamin" 9 . Gender juga diartikan sebagai "perbedaan yang yang terlihat antara laki-laki dan perempuan dilihat dari segi nilai dan tingkah laku"10

Gender merupakan behavioral differences (perbedaan perilaku) antara lakilaki dan perempuan yang diciptakan atau dikonstruksi secara sosial, yakni perbedaan diciptakan dan dikonstruksikan oleh manusia (bukan kodrat) melalui proses perkembangan kultural dan sosial. Dapat disimpulkan bahwa gender dapat berubah seiring perkembangan dari tempat ke tempat, dari waktu ke waktu, bahkan dari kelas ke kelas ${ }^{11}$

Berbeda dengan jenis kelamin Gender bukan kodrat manusia ataupun ketentuan Tuhan tetapi dapat diciptakan, sebab itu gender berkaitan dengan proses keyakinan bagaimana laki-laki dan perempuan mengambil dan melaksanakan perannya dan bertindak sesuai dengan tata nilai yang berkembang dalam lingkungannya berdasarkan perkembangan maupun perubahan sosial dan budaya di tempat mereka berada. Dengan kata lain, gender adalah pembedaan antara perempuan dan laki-laki dalam peran, fungsi, hak, perilaku yang dibentuk oleh ketentuan sosial dan budaya setempat dan akan berubah seiring perubahan zaman.

Table berikut 1 akan dipaparan perbedan antara jenis kelamin dan gender secara garis besar : ${ }^{12}$

\footnotetext{
9 Hasan Shadily, Kamus Inggris Indonesia, cet. XII, (Jakarta: Gramedia, 1983), hlm. 265 10 Ibid.

11 Riant Nugroho, 2008, Gender Dan Administrasi Publik, Pustaka Pelajar, yogyakarta, hlm.32

12 Trisakti Handayani dan Sugiarti, 2006 Konsep dan Teknik Penelitian Gender, Malang: Umm Press. 2006 hlm.
} 6. 


\begin{tabular}{|c|l|l|}
\hline Karakeristis & \multicolumn{1}{|c|}{ Seks } & \multicolumn{1}{c|}{ Gender } \\
\hline Sumber pembeda & Tuhan & Manusia (masyarakat) \\
\hline Visi misi & Kesetaraan & kebiasaan \\
\hline Unsur Pembeda & Biologis (alat reproduksi) & $\begin{array}{l}\text { Kebudayaan (tingkah } \\
\text { laku) }\end{array}$ \\
\hline Sifat & $\begin{array}{l}\text { Kodrat, tertentu, tidak dapat } \\
\text { dipertukarkan }\end{array}$ & $\begin{array}{l}\text { Harkat, martabat dapat } \\
\text { dipertukarkan }\end{array}$ \\
\hline Dampak & $\begin{array}{l}\text { Terciptanya nilai-nilai } \\
\text { kesempurnaan, } \\
\text { kenikmatan, kedamaian } \\
\text { dll. sehingga } \\
\text { menguntungkan kedua } \\
\text { belah pihak. }\end{array}$ & $\begin{array}{l}\text { Terciptanya normanorma/ } \\
\text { ketentuan tentang "pantas" atau } \\
\text { tidak pantas" lakilaki pantas } \\
\text { menjadi pemimpin, perempuan } \\
\text { pantas dipimpin dan lainlain, } \\
\text { yang sering merugikan salah } \\
\text { satu pihak, kebetulan adalah } \\
\text { perempuan }\end{array}$ \\
\hline Keberlakuan & $\begin{array}{l}\text { Sepanjang masa, dimana } \\
\text { saja, tidak mengenal } \\
\text { perbedaan kelas }\end{array}$ & $\begin{array}{l}\text { Dapat berubah, musiman dan } \\
\text { berbeda antar kelas }\end{array}$ \\
\hline
\end{tabular}

Berdasarkan dari beberapa definisi yang telah disebut dapat ditarik kesimpulan bahwa gender dapat membedakan antara laki-laki dan perempuan dipengaruhi beberapa hal seperti perkembangan zaman, sosiokulural dan akan selalu berubah berdasarkan dinamika yang berkembang dalam masyarakat dengan mengesampingkan factor biologis.

Tuntutan akan kebutuhan hidup gaya hidup tidak dapat dipungkiri bahwa tidak ada lagi batasan antara laki dan perempuan, bahkan realitanya karena tuntutan kebutuhan hidup yang pada dasarnya tidak menyengi profesi selain hal tersebut masih banyak factor-faktor lain yang mempengaruhi dinamika gender bahkan Di era Pop culture saat ini sudah hamper tidak lagi terlihat perbedaan antara plaki-laki dan perempuan dalam hal pengambilan peran dalam kehidupan sehari baik hal tersebut berkaitan dengan pekerjaan profesi, dan hobi. Perkembangan zaman saat ini terkadang dianggap tabu dilakukan oleh perempuan 
209 | MUSAWA, Vol. 11 No. 2 Desember 2019 : 202 - 221

sekarang sudah dianggap sebagai hal yang biasa sebagai contoh perempuan saat ini.

Secara sosio kultural yang tumbuh sebagai sebuah nilai yang terdapat dalam masyarakat khususnya di indonesia contoh perempuan itu identik dengan lemahlembut, cantik, emosional, atau keibuan. Sementara laki-laki dianggap kuat, rasional, perkasa. Perubahan ciri dari sifat-sifat itu dapat terjadi dari waktu ke waktu dan dari tempat ke tempat yang lain. ${ }^{13}$

Tentunya karakter gender akan selalu berubah-ubah sesuai dengan perubahan zaman tempat, budaya dan factor-faktor lain yang mempengaruhi, sebagai contoh perempuan-perempuan yang ada di pedesaan yang mana bertani dan berkebun merupakan mata pencahariannya terlihat lebih kuat secara fisik sebagai pembatasan peran bahwa peran perempuan tidak dapat melebihi peran laki-laki. dari pada perempuan-perempuan yang berada di perkotaan dimana pekerjaan tidak cendrung tidak menonjolkan fisik namun lebih menonjolkan pada kebebasan mengambil peran yang setara dengan laki-laki atau bahkan melebihi peran laki-laki. dimana masyarakat tersebut Terlepas dari hal tersebut tidak dapat dipungkiri masih ada yang masih menganggap hal yang berkaitan dengan profesi pekerjaan dan hobi tertentu tersebut sebagai hal yang tabu yang masih memegang teguh adat istiadat kultur yang berlaku dalam masyarakat tersebut.

\section{Androgini}

Definisi androgini dalam Kamus Lengkap Psikologi oleh J. P. Chaplin, androgenic (androgeni), menyebabkan atau mengarahkan pada kepriaan atau kejantanan. Selanjutnya androginitas (androgyneity) menurut kamus ini adalah antropologi, berupa konsep berdasarkan anggapan bahwa individu itu memiliki potensialitas bipoler dalam seks, sampai ia berubah jenis kelaminnya secara definitif melalui upacara keagamaan sukunya. ${ }^{14}$

13 Mansour fakih : 2010, Analisis Gender Dan Transformasi Sosial, Yogyakarta : Pustaka Pelajar, hlm. 9

14 Chaplin,J. P. 2011. Kamus Psikologi Lengkap. Jakarta: PT Raja Grafindo. hal. 156 
Sedangkan Reber (2010), definisikan androgini merupakan kondisi yang di dalamnya terdapat beberapa ciri pria dan beberapa ciri wanita hadir bersamaan dalam satu individu yang sama. ${ }^{15}$

Androgini menurut beberapa pakar salah satunya adalah Sandra L. Bern (1974,1981), menjelaskan bahwa Androgini berasal dari bahasa Yunani, yang secara harfiah terdiri dari dua kata yakni andro ialah pria dan gyne ialah wanita. Androgini adalah suatu istilah yang menggambarkan kesatuan perilaku dan karakteristik kepribadian yang secara tradisional dikenal sebagai feminin dan maskulin. Bem menekankan bahwa seorang androginus bukanlah orang moderat, yang berada di tengah-tangah antara maskulin dan femininitas yang ekstrem. Tetapi seorang androginus memandang bahwa dirinya mengombinasikan ciri-ciri maskulin dan feminin yang kuat. Selanjutnya salah satu yang dimiliki sifat jantan menurut Bem yakni ambisi, percaya diri, dan lainlain, sifat wanita yakni kasih sayang, lemah lembut, dan lain-lain, dan sifat netral yakni jujur, bahagia, dan lainlain. ${ }^{16}$

Istilah Androgini dewasa ini identik dengan seorang pria yang biasa menyerupai wanita dalam bertingkah laku layaknya wanita atau sebaliknya wanita yang bertingkah laku layaknya seorang pria, anggapan tersebut hanya melihat dari satu sisi namun sesungguhnya secara radikal dalam pengistilahan tersebut keliru jika ditinjau dari persfektif teori androgini. Sebagaimana apa yang diungkapkan spencer yang dikutip Archer. S.L dalam bukunya yang berjudul Interventions For Adolescent Identity Development. Sebagai suatu konsep jender mengacu pada pengertian bahwa pada dasarnya seseorang dilahirkan sebagai laki-laki atau perempuan dalam memahami keberadaan peran dalam kehidupan sosial akan mengalami perubahan be waktu, tempat, kultur, bangsa maupun peradaban. Keadaan tersebut mengalami perubahan seiring perubahan zaman, jender

15 Hartanti, L. (2012). Persepsi Karir dalam Gender. Diakses pada tanggal 2 November 2019 pukul 09:54 dari http://lanny.mhs.narotama.ac.id/20 /presepsi-karir-dalam- gender/.

16 Bem, Sandra L. (1974). The measurment of psychological androgyny. Journal of Consulting and Clinical Psychology, Vol.74, No.2, 155-162. Diunduh pada tanggal 02 November 2019 dari http://www.academia.edu/3319604/The_measurement_of_psychological_androgyny 
merupakan interpretasi mental dan kultur terhadap perbedaan kelamin dan hubungan laki-laki perempuan. ${ }^{17}$

Berdasarkan beberapa definisi diatas dapat dibuat kesimpulan bahwa pada dasarnya androgini merupakan sebuah sifat yang melekat pada pada diri seseorang yang tidak dapat dipisahkan satu sama lain yaitu sifat maskulin dan sifat feminin. Maskulin yang dimaksudkan diatas adalah sikap menonjolkan sikap ke priaan dalam hal ini sikap yang meibatkan fisik, mandiri, agresif dan kuat. sedangkan faminin yang dimaksudkan tersebut adalah sikap yang lebih menonjolkan sikap ke wanitaan dalam hal ini sikap yang melibatkan perasaan kelembutan dan estetika.

Era sekarang dengan semakin tingginya tuntutan kehidupan dan kebutuhan yang semakin tinggi sudah tidak ada lagi batasan atara pria dan wanita sebagai contoh banyak pekerjaan atau profesi yang melibatkan fisik yang seharusnya dilakukan oleh pria namun dilakukan oleh wanita seperti begitupula sebaliknya banyak pekerjaan atau profesi yang banyak melibatkan perasaan, kelembutan dan estetika dilakukan oleh pria Sebagai contoh pria yang memiliki profesi sebagai pekerja salon, sebagai chef, namun disisi lain banyak wanita yang berprofesi sebagai pekerja lapangan seperti reporter, atlet panjat tebing dan lain sebagainya.

Lerner dan Spanier membagi karakteristik maskulin dan feminism sebagaimana table berikut ini $:^{18}$

Table 2 perbedaan Maskulin dan Feminin

\begin{tabular}{|l|l|}
\hline \multicolumn{1}{|c|}{ Maskulin } & \multicolumn{1}{c|}{ Feminin } \\
\hline $\begin{array}{l}\text { Percaya pada kemampuas diri sendiri } \\
\text { (self relient) }\end{array}$ & Mudah menyerah (yielding) \\
\hline $\begin{array}{l}\text { Mempertahankan pendapat sendiri } \\
\text { (defend of believe }\end{array}$ & Riang gembira (cheerfull) \\
\hline Mandiri (independen) & Malu (shy) \\
\hline Atletis & Penuh kasih sayang \\
\hline Asertif & Suka dipuji (flattereble) \\
\hline
\end{tabular}

17 Archer, S.L. (editor),. (1994). Interventions for Adolescent Identity Development, London: Sage. hal 132 18 Santrock (2003) John W. Adolescence. Perkembangan Remaja. Edisi Keenam. Jakarta: Erlangga. Hal. 328 


\begin{tabular}{|l|l|}
\hline $\begin{array}{l}\text { Berkepribadian yng kuat (strong } \\
\text { personality) }\end{array}$ & Setia (loya)l \\
\hline Berkuasa & Sulit mengambil keputusan \\
\hline Analitis & Tidak mandiri \\
\hline $\begin{array}{l}\text { Memiliki kemampuan kepemimpinan } \\
\text { (has leadership ability) }\end{array}$ & $\begin{array}{l}\text { Sensitif kepada kebutuhan orang lain } \\
\text { (sensitive to the needs of others) }\end{array}$ \\
\hline $\begin{array}{l}\text { Mampu menghadapi resiko (willing the } \\
\text { risk) }\end{array}$ & Pengertian (understanding) \\
\hline $\begin{array}{l}\text { Mudah mengambil keputusan (make is } \\
\text { decision easly) }\end{array}$ & Mudah Merasa Iba \\
\hline $\begin{array}{l}\text { Memenuhi kebutuhan sendiri (Self } \\
\text { sufficient) }\end{array}$ & $\begin{array}{l}\text { Mampu meredakan perasaan terluka (eager } \\
\text { to the hurt fealing) }\end{array}$ \\
\hline Dominan & Halus tutur kata (soft spoken) \\
\hline Bersifat maskulin & Hangat warm \\
\hline $\begin{array}{l}\text { Bersedia memegang suatu sikap (willing } \\
\text { to the stand }\end{array}$ & Lembut tender \\
\hline $\begin{array}{l}\text { Bertindak sebagai pemimpin (action a } \\
\text { leader) }\end{array}$ & Kekanak-kanakan (childlike) \\
\hline $\begin{array}{l}\text { Agresif } \\
\text { Suka berkompetisi (competitive) }\end{array}$ & Mudah tertipu (gullible) \\
\hline Ambisius & Mencintai anak-anak (love children) \\
\hline
\end{tabular}

Berdasarkan table pembanding antara sikap maskulin dan feminin dapat disimpilkan bahwa prilaku maskulin identik dengan prilaku dominan anak lakilaki dan sebaliknya prilaku dan sikap feminism identik dengan anak-anak perempuan, namun tidak menutup kemungkinan ada hal-hal yang sikap dan prilaku wanita yang menyenangi hal-hal yang berbau maskulin begitu juga sebaliknya ada sikap dan prilaku feminism yang disukai pada anak-anak laki-laki.

Batasan antara feminin dan maskulin dalam konteks sosiokultural tentu berbeda-beda disetiap tempat, ruang dan waktu terkadang dalam suatu masyarakat 
213 | MUSAWA, Vol. 11 No. 2 Desember 2019 : 202 - 221

menganggap prilaku tersebut cendrung feminism namun di tempat lain dianggap sebuah sifat atau prilaku maskulin. Terlepas dari hal tersebut prilaku feminin dan maskulin akan terbentuk oleh lingkungan dimana tempat mereka berada.

Secara garis besar ada 4 kemungkinan yang terjadi pada masing-masing individu Sandra bem :

1. Ciri femininnya tinggi dan maskulinitas tinggi, individu seperti ini disebut androgyny.

2. Ciri femininnya tinggi dan maskulinitas rendah disebut feminine.

3. Ciri femininnya rendah maskulinitas tinggi disebut masculine.

4. Ciri femininnya rendah maskulinitas rendah, individu seperti ini disebut undifferentiated

Fenomena permainan anak yang mengguanakan gadget merupakan salah satu factor yang sangat penting dalam pembentukan karakter gender sebab banyak diantara orang tua menggunakan media gadget sebagai bentuk permainan anaknya untuk mempermudah dalam pengasuhan anak atau banyak yang beranggapan gadget dapat meningkatkan perkembangan kecerdasan anak contohnya game arcade, menggambar, menulis, menghitung dan lain-lain. Pernyataan tersebut tidak sepenuhnya keliru akan tetapi para orang tua harus melihat perkembangan dari sisi social anak dalam pergaulan ini dapat memberi dampak terhadap perkembangan karakter gender anak.

Seyogyanya dalam persfektif teori andrgoni sebagaimana yang telah diungkapkan bahwa pada prinsipnya manusia memiliki dua sifat yang mutlak dimiliki oleh manusia yaitu maskulin dan feminine, akan tetapi kecendrungan kearah mana hal tersebut dipengaruhi oleh waktu, tempat, budaya dan lingkungan sekitar jadi peran orang tua dalam pengasuhan anak seyogyanya bisa dibagi dengan jelas sebab secara naluri dari persfektif teori gender antara maskulin dan feminine dimiliki oleh setiap manusia Untuk tidak memperluas apa yang sebenarnya dibahas dalam Teori androgini ini, teori androgini hanya terbatas pada karakter sifat manusia tidak berbicara mengenai kelainan seksual atau disorientasi seksual.

Lingkungan sebagai pebentuk karakter gender dapat dilihat sebagai suatu paling berpengaruh dalam kasus pembentukan karakter gender pada anak Peran 
keluarga terutama pembagian pengasuhan antara ayah dan ibu lebih banyak memberikan pengaruh kuat sebab memberikan efek yang secara langsung berkaitan dengan perkembangan perilaku anak, peran keluarga dapat berfungsi langsung sebagai lingkungan kehidupan nyata untuk memperaktekkan aspekaspek perilaku tersebut, apa yang dilakukan, apa yang diajarkan, dan apa yang diperlihatkan orang tua dapat dipraktekkan oleh anak sebagaima adanya anggapan bahwa anak merupakan peniru yang ulung apa yang dilihat dengan cepat dipraktekkan oleh anak.

Perkembangan teknologi dan informasi berkembang sangat pesat hal ini dapat memberikan dampak positif dan dampak negatif, sekali lagi orang tua merupakan filter terhadap perkembangan teknologi dan informasi terhadap pola asuh anak, dalam beberapa kasus perkembangan teknologi memberikan efek yang praktis dalam pengasuhan anak mempermudah namun disisi lain dapat memberikan efek menjadi anak yang individualistic dimana anak tersebut tidak menjadi peduli terhadap apa yang terjadi pada lingkungan sekitarnya, sosialisasi anak merupakan hal yang sangat penting dalam perkembangan gender anak memiliki teman sepermainan dapat memberikan efek social yang baik terhadap perkembangan anak, peran orang tua dalam pengawasan terhadap teman sepermainan dan apa yang dimainkan oleh anak sangat penting untuk memberi kenyamanan kepada anak sekaligus memberikan perlindungan terhadap anak, Namun terkadang kesibukan dalam memenuhi kebutuhan dalam keluarga sehingga waktu bersama keluarga menjadi sedikit dalam memberikan pengasuhan terhadap anak, namun tidak dapat dipungkiri bahwa faktor ekonomi sebagai tuntutan kehidupan merupakan salah satu faktor yang sangat penting dalam keberlansungan keluargan, akan tetapi albibi tersebut tidak dapat dijadikan alasan untuk tidak membagi waktu dalam mengasuh anak, sehingga kontrol terhadap pengasuhan menjadi berkurang.

Ketika mengingat kembali di masa lampau maka betapa banyaknya jenis permainan yang bisa meningkatkan perkembangan social anak seperti permainan petak umpet, kelereng, Lompat tali, tumbu-tumbu blanga dan lain-lain, hanyalah sebagian kecil dari banyaknya jenis permainan tradisional yang ada di Indonesia 
permainan tradisional erat kaitannya dengan fungsi psikologis perkembangan anak. Tak sekadar memberi perasaan senang bersama teman-teman dalam menghabisikan waktu dimasa kecil namun juga, fungsi kognitif, social. Tapi ada aspek emosional yang sehingga dapat membentuk karakter gender anak. Ketika kita menaganiaisa permainan tradisional anak yang melibatkan dua orang atau bahkan kelompok, maka dapat meningkatkan afiliasi dengan teman sebaya, kontak sosial, konservasi, dan ketrampilan social, namun tidak dapat dipungkiri bahwa sering terjadi konflik pada teman sepermainan anak sehingga kembali lagi pada sangat penting kehadiraan orang tua dalam memberikan perasaan aman dan perlindungan kepada anak.

Pembagian tugas dan keberadaan oran tua dalam mengasuh anak menjadi muara dalam pembentukan karakter gender anak, selain itu penerapan pemilihan pola pengasuhan, orang tua harus mampu membagi peran dan pembagian tugas dalam pembentukan karakter gender anak aktivitas dan permainan apa yang cocok untuk gender anak-anaknya. seyogyanya, anak laki-laki diberikan permainan dan aktivitas permainan yang intens berhubungan dengan yang mengandalkan kekuatan fisik, sehingga nantinya anak bisa menjadi anak yang memiliki sifat dominan maskulin. Sedangkan anak perempuan deberikan permainan atau aktivitas yang melibatkan perasaan, sehingga nantinya anak tumbuh menjadi pribadi yang memiliki lebih menonjolkan sifat feminin. Hendaknya anak laki-laki orang tua lebih selektif dalam hal pola asuh dan pemilihan aktifitas terhadap anak.

Pertanyaan yang akan muncul apakah salah anak laki-laki memiliki sifat feminine atau apakah salah anak perempuan memiliki sifat maskulin? Tentunya tidak ada salahnya sebab secara lahiriah manusia memiliki kedua sifat tersebut namun alangkah baiknya jika dalam penerapan anak laki-laki lebih menonjolkan sisi maskulin dari pada sisi feminine begitu juga sebaliknya oleh karena itu sangat penting berbicara mengenai peranan orang tua dalam membagi tugas dalam mengasuh anak sehingga menciptakan keseimbangan karakter gender anak.

\section{Pembentukan Identitas Gender}

Prinsip dasar pembelajaran sosial pembelajan terjadi melalui peniruan/imitation dan penyajian contoh perilaku. Dalam hal ini seseorang belajar 
dapat mengubah perilakunya sendiri dengan mlihat atau menyaksikan cara orang atau sekelompok orang merespon sebuah stimulus tertentu. ${ }^{19}$

Menurut Bandura sebagian besar manusia belajar melalui pengamatan secara selektif dan mengingat tingkah laku orang lain. Seseorang belajar menurut teori ini dilakukan melalui pengamatan tingkah laku orang lain (model), dari hasil pengamatan tersebut selanjutnya mengaitkannya dengan cara menghubungkan pengalaman baru dengan pengalamansebelumnya, sehingga seseorang dapat mengimplementasikan tingkah laku yang diamati. ${ }^{20}$

Dalam perkembangan masyarakat tradisional anggapan dalam hal pengasuh anak selalu mengacu pada atau tugas dari pada seorang ibu sedangkan mencari nafkah merupakan tanggung jawab seorang ayah, begitupula ada anggapan anak lebih meniru karakter ibu atau ayahnya dikarenakan kedekatan seorang anak lebih intens dengan salah satu dari kedua orang tuanya entah itu ayah atau ibunya sendiri, sehingga perkembangan anak mengikuti salah satu karakter dari orang tuanya, Tuntutan kehidupan dijaman modern memang tidak lepas dari perkembang anak bagaimana intensisitas dalam hal pengasuhan kepada anak oleh kedua orang tuanya adanya anggapan cukup membeli banyak permainan itu sudah lebih dari cukup memenuhi kebutuhan perkembangan anak.

Menurut teori belajar sosial, secara rinci dasar kognisi dalam proses belajar dapat diringkas dalam 4 tahap yaitu : atensi/perhatian; retensi/mengingat; reproduksi gerak; dan motivasi.

1. Atensi/Perhatian model/objek tidak dapat ditiru jika tidak diadakan pengamatan sehingga dapat dipersepsikan secara tepat

2. Retensi jadi seorang pengamat mengamati dan menyimpan dalam memori ingatan tentang tingkah laku model/objek yang telah diamati di dalam ingatannya karena tingkah laku tersebut harus bisa diingat kembali.

19 Lawrence A. Pervin, dkk., Personality: Theory and Researc, terj. A.K. Anwar, Psikologi Kepribadian: Teori dan Penelitian, Edisi IX ( Cet,I; Jakarta: Kencana, 2010), h. 432

20 Mulyono Abdurrahman, 2003, Pendidikan Bagi Anak Berkesulitan Belajar, (Jakarta: Rineka Cipta,) , hlm. 3738. 
217 | MUSAWA, Vol. 11 No. 2 Desember 2019 : 202 - 221

3. Reproduksi gerak, dilakukan dengan mengamati model selanjutnya pengamat mencoba untuk menirukan ulang tingkah laku model yang diamatinya.

4. Penguatan dan motivasi tingkah laku dicontoh melalui tindakan-tindakan terpuji yang memiliki motivasi untuk menirukan. ${ }^{21}$

Adanya ungkapan bahwa buah yang jatuh tidak jauh dari pohonnya ungkapan tersebut menekankan pembentukan karakter anak tergantung dari kedekatan anak pada anaknya, kecendrungan anak akan meniru apa yang mereka lihat tentunnya hal tersebut merupakan bentuk dari pembelajaran anak melalui pengasuhan oleh orang tua mereka, Pengenalan gender secara tidak langsung juga dapat diajarkan kepada anak melalui permainan yang dipilihkan Misalnya, anak perempuan biasanya bermain dengan boneka dengan mrepresentasikan boneka tersebut adalah anak, hal tersebut secara tidak lansung memberikan dampak penciri peran mereka nantinya ketika besar nanti yaitu wanita sebagaimana kodratnya dengan mangasuh anak. Pada anak laki-laki peran atau jenis permainan yang dipilih adalah permainan yang melibatkan fisik, gerak dan tanggung jawab biasaya kita melihat permainan yang menjurus pada peran tanggung jawa kepada keluarga dan melindungi perempuan.

Pada usia anak usia dini sebaiknya memperkenalkan gender karena pada masa masa keemasan. Pembentukan konsep diri pada anak akan memberikan pengaruh pada pembentukan kepribadian dan pemahaman gender anak saat ia dewasa. Pengenalan perbedaan peran gender harus dilakukan secara tepat, hal ini dapat dilakukan dengan memilih permainan yang tepat, Memberikan pemahaman terhadap gender merupakan hal yang penting dilakukan oleh orang tua melalui permaian, ini merupakan sebuah tantangan dengan dinamika pemahaman masyarakat yang berubah dari masa ke masa tergantung sosiokultural yang melekat pada masyarakat contohnya adanya anggapan bahwa warna cerah seperti

21 Muhammad Fathurrohman dan Sulistyorini, 2012. Belajar dan Pembelajaran. Teras: Yogyakarta, hal 233 234 
pink (merah jambu) atau kuning lebih edentik dengan wanita, pada dasarnya yang diajarkan adalah mengenai peran dan tanggung jawabnya. Penting bagi orang tua untuk memberikan pemahaman gender agar anak tidak terlanjur merasa nyaman pada kondisi yang salah.

Konsep diri merupakan penlaian tentang dirinya oleh orang lain yang menyangkut aspek physical, perceptual, dan attitudinal (fisik, persepsi, dan kesikapan). Konsep diri merupakan.Dalam kaitannya dengan penilaian tersebut, Cooley mengeluarkan teori tentang Looking Glass Self. Artinya, setiap terjadi hubungan sosial dimana seseorang itu terlibat merupakan suatu cerminan diri gabungan dalam identitas orang itu sendiri. ${ }^{22}$

Pada perkembangan masa awal anak-anak, teman sebaya atau teman sepermainan merupakan hal utama yang dapat memengaruhi peran gender. Teman sebaya dianggap dapat meciptakan perilaku orientasi gender pada usia 3 tahun, dan pengaruh ini meningkat seiring pertambahan usia Anak-anak, hal ini dapat kita jumpai dimana anak laki-laki yang kecendrungannya berprilaku seperti "wanita" atau anak perempuan berprilaku "laki-laki".

Pemelihan permainan pada usia dini lebih dipengaruhi secara kuat oleh teman sebaya atau teman sepermainan dan media dibandingkan oleh model yang anak-anak lihat dirumah. Namun demikian terkadang sikap orang tua dan teman sebaya bekerja saling melengkapi. Teori kognitif social melihat teman sepermainan memiliki pengaruh yang saling melengkapi satu sama lain terhadap sosialisasi, tetapi sebagai bagian dari sistem budaya yang kompleks yang melampaui orang tua dan juga agen sosialisasi yang lain. Berdasarkan perkembangan zaman Teori belajar sosial melihat bahwa anak yang banyak menonton siaran televise lebih cendrung meniru peran model yang mereka lihat media TV atau media sosial. 
219 | MUSAWA, Vol. 11 No. 2 Desember 2019 : 202 - 221

\section{KESIMPULAN}

Berdasarkan konsep teori yang telah diuraikan sebelumnya, penulis membuat suatu kesimpulan sebagai berikut :

1. Mengubah persepsi masyarakat terhadap androgini, yang menganggap bahwa androgini merupakan penyimpang "seksualitas" atau penyimpangan prilaku manusia dimana pria yang berprilaku layaknya perempuan atau sebaliknya ketika laki-laki yang berprilaku layaknya seorang seorang wanita, sebab androgini merupakan fakta bahwa sesungguhnya setiap manusia memiliki dua sifat yang tidak dapat dipisahkan satu sama lain, tergantung karakter apa yang akan di tonjolkan baik itu sisi feminism ataupun sisi maskulin.

2. Pemahaman perbedaan antara jenis kelamin dan gender diharapkan dapat memberikan edukasi tentang pemilihan jenis permainan yang dapat memberikan pemahaman peran gender bagi anak usia dini, melaui pemilihan permainan.

\section{REFERENSI}

\section{Buku}

Al-Quran Terjemahan. 2015. Departemen Agama RI. CV Darus Sunnah. Bandung.

Archer, S.L. (editor),. (1994). Interventions for Adolescent Identity Development, London.

Chaplin,J. P. 2011. Kamus Psikologi Lengkap. JPT Raja Grafindo. Jakarta.

Johnson. 1986. Teori Sosiologi Klasik dan Modern. Jilid 1. PT Gramedia: Jakarta.

Jhon M. Echols dan Hasan Shadily, 1983. Kamus Inggris Indonesia, cet. XII, Gramedia. Jakarta.

Hartanti, L. (2012). Persepsi Karir dalam Gender. Diakses pada tanggal 2 November 2019 pukul 09:54 dari http://lanny.mhs.narotama.ac.id/20 /presepsi-karir-dalam- gender/. 
Hasan Shadily, 1982. Kamus Inggris Indonesia, cet. XII, Gramedia, Jakarta.

Lawrence A. Pervin, dkk., Personality: Theory and Researc, terj. A.K. Anwar, 2010 Psikologi Kepribadian: Teori dan Penelitian, Edisi IX Cet,I; Kencana. Jakarta.

M. Fadlillah, 2017. Bermain \& Permainan Anak Usia Dini, Kencana, Jakarta.

M. Fathurrohman, dan Sulistyorini, 2012. Belajar dan Pembelajaran. Teras: Yogyakarta.

Mulyono Abdurrahman, 2003. Pendidikan Bagi Anak Berkesulitan Belajar, Rineka Cipta, Jakarta.

Mansour Fakih, 2013. Analisis Gender \& Transformasi Sosial, Pustaka Pelajar, Yogyakarta

R. Nugroho, 2008, Gender Dan Administrasi Publik, Pustaka Pelajar, Yogyakarta.

Riant Nugroho, 2008, Gender Dan Administrasi Publik, Pustaka Pelajar, Yogyakarta.

Santrock, 2003. John W. Adolescence. Perkembangan Remaja. Edisi Keenam. Erlangga. Jakarta.

T. Handayani dan Sugiarti, 2006, Konsep dan Teknik Penelitian Gender, Umm Press. Malang.

Tedjasaputra, Mayke S. 2001. Bermain, Mainan, dan Permainan. PT. Grasindo, Jakarta.

\section{Internet}

Bem, Sandra L. (1974). The measurment of psychological androgyny. Journal of Consulting and Clinical Psychology, Vol.74, No.2, 155-162. Diunduh pada tanggal $02 \quad$ November 2019 dari http://www.academia.edu/3319604/The_measurement_of_psychologic al_androgyny

Hartanti, L. (2012). Persepsi Karir dalam Gender. Diakses pada tanggal 2 November 2019 pukul 09:54 dari http://lanny.mhs.narotama.ac.id/20 /presepsi-karir-dalam-gender/. 
221 | MUSAWA, Vol. 11 No. 2 Desember 2019 : 202 - 221

Hungu. 2007. Pengertian Jenis Kelamin. Dapat dibuka pada situs http://www.scribd.com/doc/143354392/BAB-II-Tinjauan-Gender diakses tanggal pukul 1 Januari 2019

Sinclair 1995. Pengertian Jenis Kelamin, dapat dibuka pada situs http://www.scribd.com/doc/143354392/BAB-II-Tinjauan-Gender diakses pada tanggal 02 November 2019. 